\title{
THE REPRESENTATIONS OF HOMOPHOBIA IN GAY-THEMED AMERICAN MOVIES OF 1990S-2010S
}

\author{
Stella Maris Saraswati Mere \\ stella@softwareseni.com
}

\begin{abstract}
The United States is well-known for its acceptance of homosexuality. Nevertheless, homophobia remains a threat that endangers gay communities in the United States. Homophobia is an intriguing phenomenon for American filmmakers. Through gay-themed movies, those filmmakers intend to raise the awareness that homophobia is elusive to eradicate.

This study scrutinizes the representations of homophobia in the United States as seen in gay-themed American movies. The study carries out Postnationalist America Studies as the paradigm of the study which encompasses the discussions of numerous phenomena in the United States. Also, the study applies theory of representation by Stuart Hall probing the representations of homophobia in gay-themed American movies of 1990s-2010s.

The study uses nine gay-themed American movies of 1990s-2010s as the primary data of the research. The findings of the study show three representations of homophobia in the United States, which encompass religions, gender roles, heteronormativity, masculinity, and HIV/AIDS as the highlighted factors that incite homophobia. By highlighting those major factors of homophobia, the filmmakers come up with two major intentions. The first intention is the movies as means to criticize the society who conforms to strict religious beliefs, traditional gender roles, masculinity, and heteronormativity. The conformity has led the society to commit homophobia, hence making homophobia elusive to eradicate. The second intention is the movies are aimed at encouraging gay communities to keep fighting for their issues and equality.
\end{abstract}

Keywords: Homosexuality, Homophobia, the United States, Gay-themed American Movies

\section{Introduction}

The United States has recognized the existence of gay communities following its first emergence during $19^{\text {th }}$ to $20^{\text {th }}$ century (Bronski, 2011: 65-66). However, the first emergence of gay communities was negatively received by the authorities. The negative attitudes towards gay communities at that time were mostly triggered by its negative association with crimes and abnormalities (Bullough, 2005). It was not until the 1960s that finally gay communities were eventually recognized. In the late 1960s, gay organizations and movements which were once secretive finally became public (Jagose, 1996: 25-26). The organizations gradually became popular all over the country. Their contributions documented in media attracted public to gain respect towards the existence of gay communities in the United States. 
As gay communities have affirmed their existence through positive contributions, the United States eventually opens a total access to gay communities to express their identity and to fully contribute to the society. A great number of LGBT figures have been recognized through their remarkable works which successfully empower the society. The world's most famous drag queen, Ru Paul, is a prominent LGBT figure, who empowers young gay artists to enhance their creativity and passion for fashion, make-up, and entertainment. Another considerable LGBT figure is Harvey Milk, who became a prominent gay politician in the 1970s.

The presence of prominent gay figures is not the sole proof that the United States has acknowledged the existence of LGBT communities. Thirty six states have even chartered the same-sex marriage law, which indicates another positive recognition from the country towards LGBT community. Most importantly, Barack Obama has confirmed his support for the legalization of same-sex marriage in the United States. ${ }^{1}$

\footnotetext{
${ }^{1}$ Reilly, Mollie. "Obama Praises Supreme Court's Decision To Legalize Gay Marriage Nationwide." Huff Post Politics. Huffington Post, 26 June 2015. Web. 16 Dec. 2015.
}

Despite the United States' support for gay people, the country is still struggling with homophobia. There has been a great number of murder, violence, and suicide cases which were motivated by homophobia. Among those cases, hatecrime places as a type of homophobia which is often addressed to gay people. In 2013, FBI released a statistic data mentioning that $20.8 \%$ of hate crime were incited by homophobia ${ }^{2}$. In addition to hate crime and suicide, homophobia causes depression and constant fear among gay people which unfortunately eliminates chances for gay people to live normally and embrace a better future. Homophobia against gay athletes is an example on how homophobia risks the future of theirs. A recent study on homophobia in sports entitled "Out on The Fields" launches a statistics report mentioning that the US ranks worst in homophobia against gay athletes $^{3}$. Specifically, this study demonstrates that over $80 \%$ of homosexual athletes choose to keep their sexual orientation secret.

\footnotetext{
${ }^{2}$ Federal Bureau of Investigation. "FBIVictims”.fbi.gov. Retrieved on December 16, 2015 from https://www.fbi.gov/news/stories/2014/december/la test-hate-crime-statistics-report-released ${ }^{3}$ Gregory, Sean. "U.S. Ranks Worst in Sports Homophobia Study." TIME. TIME, 9 May 2015. Web. 19 June 2015
} 
The increasing number of homophobic acts is intriguing. People might question why homophobia still takes place in the country which is well-known for its immense supports to gay people. Ironically, the number is increasing while the country continuously endorses equality for gay people. Through various means such as art and social media, the country has encouraged people to help preserve the equality for gay people. Nevertheless, the attempts still face challenges.

Regarding art as one means to help preserve equality for gay people, literary works such as plays and movies, consistently promote equality for gay people. For movies, there has been a great deal of gay-themed American movies portraying the lives of gay people, particularly in the United States. Critically acclaimed American movies, namely, Milk (2008) and The Kids Are Alright (2011) are examples of movies demonstrating positive contributions made by American gay people. On the other hand, Saving Face (2004), Philadelphia (1993), and The Normal Heart (2014) are few names of American movies disclosing the ugly truth of homophobia in the United States.

Intrigued by the representations of homophobia in gay-themed American movies, this study aims to answer the question on why movies portraying homophobia are still released in the modern United States despite the country’s tremendous support towards homosexuality. In order to answer the question, the study attempts to further probe how homophobia in the United States is represented in such movies. Also, the study intends to reveal the triggers behind homophobic acts against homosexuals in the United States. Since there is a great number of gay-themed American movies which have been released in the last 25 years, this study uses some of the movies as the object of this research. These movies are famous for depicting homosexuality and homophobia in the modern United States, which is useful for figuring out the representations of homophobia in the country as well as disclosing the triggers behind homophobic acts.

This study carries out the concept subalternity as it confirms the basic idea of Post-Nationalist American Studies that rejects American Exceptionalism. It also reflects on problems of the minority and oppressed groups since the groups as parts of the United States. Hence, subalternity acknowledges the necessity of encompassing racial/ethnic minorities, gender hierarchy, and sexuality hierarchy 
as pivotal subjects to be studied in the context of Post-Nationalist American Studies (Rowe, 2000: 25).

Since subalternity encompasses the discussions on sexuality and sexual hierarchy on grounds of American Studies, the use of theories surrounding homosexuality and homophobia is pivotal to scrutinize the problems of gay communities in the United States. Specifically, the study carries out the theory of homophobia that is seminal to foreground the representations of homophobia in the United States as seen in gay-themed movies of 1990s to 2010s. The following explanation offers concise explanations on homophobia in general and how it is manifested in the society.

The term homophobia was first introduced by George Weisenberg in 1972. The word refers to the situation where heterosexuals show the fear of being close to homosexuals (Shidlo, 1994: 177). However, the term is problematic as heterosexuals who are homophobic frequently display "negative attitudes" towards homosexuals (Herek qtd. in Shidlo, 1994: 177). For years, homophobia has been an institutionalized practice against homosexuals. In other words, negative attitudes shown towards homosexuals are ironically acceptable in the society and those attitudes shape the way homosexuals perceive their homosexuality (Forstein, Gonsiorek, and Loulan qtd. in Shidlo, 1994: 178).

In regards to causes of homophobia, religions, heterosexism ${ }^{4}$, inaccurate representations of homosexuals in media, and HIV/AIDS are immensely referred as the causes of homophobia (Roggemans, 2015: 254; Girshick 337 qtd. in Jagose, 1996: 94). In accordance with religions, Roggemans et al (2015: 270) revealed that religious people generally show negative attitudes towards homosexuals. Religious people believe that homosexuality is against religions' teachings; hence it is permitted to display negative attitudes towards homosexuals (Duck and Hunsberger qtd. in Roggemans, 2015: 258). Heterosexism as one main trigger of homophobia asserts that homosexuality violates traditional gender roles and heterosexuality as the normative sexual orientation. Culturally, the traditional gender roles have adhered to the concept of masculinity and femininity.

\footnotetext{
${ }^{4}$ Tin (2003, p. 436) defines heterosexism as "a vision of social world that articulates the promotion of heterosexuality and the exclusion of homosexuality." In other words, the term is used to refer to discriminatory acts against homosexuality. Tin also adds that heterosexuality is strongly associated with theological explanation that emphasizes the ideas of men are created for women and vice versa.
} 
Homosexual men are seen as the "traitors" of masculinity. Their homosexuality has been accused of emasculating the image of men as masculine figures (Tin, 2003: 440). On the other hand, lesbian women are victimized by homophobia due to the fact that they courageously fight for their equality. In other words, their courage is seen as the violation of their femininity (Girshick, 2005: 336).

The representations of homosexuals in media have also generated homophobia. For years TV shows and movies have inaccurately portrayed homosexual characters as ridiculous, weird, violent, and even dangerous (Davis, 2005: 338). Such representations have inevitably antagonized homosexual people. They have been perpetrated and abused following the representations. In addition to the inaccurate representations, the constant misconception about HIV/AIDS and homosexuality triggers homophobia. Since the first outbreak of HIV/AIDS occurred in gay communities, people have falsely and persistently accused homosexuals as the sole carrier of HIV/AIDS (Meyer qtd in Jagose, 1996: 94). Hence, the false accusation contributes to the "growing homophobia" (Creed qtd. in Jagose, 1996: 94).
There have been many negative attitudes which can be identified as homophobia. Tin (2003: 389) mentions that verbal abuse is a form of homophobia mostly committed against the members gay community. Words such as faggot and poof are mostly slurred to humiliate homosexuals. The worst form of homophobia is hate-crime, which mostly involves physical abuse and murder. Tin (2003: 440), regards physical and sexual violence against the members of gay community as the worst form of homophobia and is mostly perpetrated by men who are "conditioned by the social climate of masculinism”. In other words, men who are homosexual are considered as unmanly. Thus, they have to be exterminated since they have spoiled the image of men as masculine.

\section{Methodology}

This study examines the representations of homophobia in the United States as seen in gay-themed American movies of 1990s-2010s. Therefore, the use of theory of representation is an essential approach of this research. According to Hall, representation is inseparable from culture (1). Hall clarifies his statement by firstly defining culture as "shared meanings". 
Through culture, people share values and meanings. This process is made possible only by language for it becomes the medium of producing meanings and values. Language is able to carry meanings as it functions as a "representational system”.

One important point highlighted by Hall in the theory of representation is the use of connotation and denotation, as the seminal process in the study of representation. Connotation and denotation are actually terms which have been introduced by the prominent semiotician, Roland Barthes. Referring to Barthes, Hall agrees that representation is not solely about finding a description of something in another thing (denotation). Representation, in fact, also takes a "broader cultural level”, which Barthes then refers as connotation (qtd. in Hall, 39). In other words, representation requires deep understandings on social or cultural backgrounds that help us understand meanings and values of particular things or phenomena.

In this study, gay-themed American movies play an important role as it carries meanings, thoughts, and expressions which are associated with homophobia in the United States. All elements of the movies, namely settings, actors, storylines, dialogues, and even titles, can describe homophobia in the United States. In regard to connotation and denotation, all movies' elements serve as the denotation. On the other hand, social or cultural explanations on homophobia and the United States can be referred as connotation.

Regarding the method of the study, the study carries out document analysis as the method of the study. There are two types of data used in the study: The primary data and the secondary data. The primary data is gay-themed American movies produced in 1990s to 2010s. More than 152 gay-themed American movies have been produced from 1990s2010s. ${ }^{5}$ However, the study only comprises nine gay-themed American movies produced in the 1990s to 2010s. The movies are Philadelphia (1993), The Incredibly True Adventure of True Girls in Love (1995), But I'm A Cheerleader (1999), Latter Days (2003), Saving Face (2004), Pedro (2008), The Wise Kids (2011), Dirty Girl (2010), and The Normal Heart (2014). There are two reasons

\footnotetext{
${ }^{5}$ The number is taken from researches called “Studio Responsibility Index” by GLAAD (Gay \& Lesbian Alliance Against Defamation) in the 2010s (2012-2016) and a study by Michael Bronski entitled, "The Queer 1990s: The Challenge and Failure of Radical Change”. Bronski's study is documented in "American Film History: Selected Readings, 1960s to the Present” edited by Cynthia Lucia, Roy Grundmann, and Art Simon (330).
} 
underlying the selection of those movies as the primary data. The first reason is those movies offer vivid portrayals of homophobia in the United States. Specifically, the movies' portrayals are hugely concerned with three major issues related to homophobia, namely religions, gender, and HIV/AIDS. The second reason is the fact that the movies come up with good intentions for both gay and heterosexual people. For gay people, the movies aim to encourage gay communities to strive for equality. For heterosexual people, the movies raise the awareness of homophobia as an institutionalized practice that is challenging to eradicate.

\section{Discussion}

\section{Connecting Religions and Homophobia} in the United States

Religions, namely Christianity, Islam, and Orthodox Judaism, generally condemn homosexuality for being inimical and against the nature. Additionally, religions negatively value homosexuality for its "non-procreative” purpose. Religions believe that sexual encounter should be conducted by a man and a woman for procreation. Therefore, due to the absence of procreation in sexual activities committed by homosexuals, homosexuality is castigated. Sands (4) argues that the sexual encounter between homosexuals is "negatively interpreted" by religions as it solely prioritizes pleasure, which is apparently considered dangerous for procreation.

The condemnation of homosexuality by religions has apparently intrigued American filmmakers to create movies that deal with the issues of homosexuality and faith. Approximately, in the last 25 years, there have been 30 gay-themed American movies that are concerned with the issues of homosexuality and religions (GLAAD, 2013-2016). Those movies also highlight that religious teachings become one main factor inciting homophobia in the United States.

Regarding the representations of homophobia and religions in the United States seen in gay-themed American movies, the study uses three movies as the primary data in the discussion about religions and homophobia. The movies are But I'm A Cheerleader (1999), Latter Days (2003), and The Wise Kids (2011).The movies generally emphasize that homophobia is triggered by religious teachings. In addition, the movies underline that Christianity is a religion frequently associated with homophobia in the United States. 
The first movie, But I'm A Cheerleader (1999) is a story of Megan Bloomfield, a teenage girl who is sent by her devout Christian parents to True Directions, a rehabilitation camp that aims to cure homosexuality. Megan is at first reluctant to go to True Directions since she never identifies herself as a lesbian, although it is obvious that she is sexually attracted by her female friends. However, as the therapy proceeds, she begins to embrace her homosexuality and falls in love with another girl at the camp.

The second movie discussed in the section is Latter Days (2003). The movie renders the romantic relationship between Aaron, a closeted gay Mormon missionary, and Christian, Davis' openly-gay neighbor. Unfortunately, their relationship faces challenges as Davis' fellow Mormon missionaries discover the relationship. Hence, Davis is excommunicated from his church and is assigned to undergo a conversion therapy to cure his homosexuality. The movie basically highlights one issue in which homophobia always confronts someone's attempt to reconcile his faith and homosexuality.

The last movie discussed is The Wise Kids (2011). The movie follows three Christian teenagers, Brea, Tim, and Laura who are also best friends to each other.
Brea is a daughter of a minister at a Baptist Church, in South Carolina who apparently begins questioning her faith. Tim is a gay teenager who dreams of becoming a director. Laura is a devout Christian, urges Tim to choose between his faith and homosexuality as she believes that he cannot choose both things. The Wise Kids explores someone's attempt to preserve his faith while reconciling it with his sexual orientation. Therefore, throughout the movie, we will be exposed to Tim's story whose coming out sparks off mixed reactions from his surroundings, including the hostile reactions from his best friend, Laura, and his brother.

Those three movies share the same points in which the all gay characters receive resentment from their families and friends. In the first movie, Megan's parents- Peter and Nancy- assert that homosexuality is unnatural and sinful. The assertion is reflected in Peter's prayer which demands God guide Megan to living a "natural, healthy, and sacred" life, which implies his hope for Megan to dodge from homosexuality. Those words are the antithesis of how homosexuality is perceived in Christianity. In other words, Christians often use unnatural, sinful, and unhealthy as the terms that affirm their condemnation of homosexuality 
(Roggemans, 2015: 258). Moore (2003:

12) explains that Christians often address those strong terms to homosexuals as they believe that homosexuality is against the will of God which is written in the Bible and dangerous for human existence. In the context of the movie, Peter's prayer can be inferred as Peter's resentment over his daughter's homosexuality.

Peter's hope may resemble his concern over his daughter's homosexuality. However, his hope can also be associated the Christian view on sexuality that mainly emphasizes heterosexuality. As mentioned previously, Christianity lives by the concept that humans play the key role in sustaining the procreation purpose as God has commanded in the Scripture. Hence, heterosexual marriages are seen as the pivotal way that can help humans accomplish the procreation purpose. In addition, Christianity also takes heterosexual marriages for happiness. As Moore (2003: 12) writes, Christians believe the Bible has guaranteed happiness through heterosexual marriages.

Connecting Peter's prayer and the Christian view on marriage, it can be inferred that Peter is concerned that Megan will not be able to fulfill her role as a Christian who is able to accomplish the procreation purpose. Besides, Peter fears that Megan will be trapped into an unforgivable sin if she preserves her homosexuality. Thus, through his prayer, he attempts to warn Megan about her homosexuality in hope that she suddenly converts herself to be a heterosexual woman.

In Latter Days, Aaron's homosexuality is also considered unforgivable and sinful to his devoutly Mormon parents. Aaron's mother, Susan throws a hostile reaction after Aaron declares that homosexuality is a part of his identity. She claims that the homosexuality is an evil act that is unforgivable. Susan's firm statements which correlate Aaron's homosexuality and God vividly reflect the opposition that the Mormon Church has towards homosexuality. The Mormon Church is undeniably notorious for its opposition towards homosexuality. In the United States, the Church even remains as one of Christian denominations defying homosexuality and associated with homophobia.

The opposition towards homosexuality comes from the fact that Mormons conform to the Law of Chastity. As cited in the official website of the Mormon Church, The Law of Chastity is a law in the Mormon Church that 
accentuates the sacredness of "sexual purity” (lds.org). The core principles of the law are the prohibitions of sexual activity before marriage and adultery. In addition, the law recognizes homosexuality as a serious sin. According to the Church, homosexuality is considered a sin for it prevents humans from receiving blessings and happiness that can be achieved through family. In other words, the law highlights that heterosexual marriage brings humans happiness and abundant blessings.

Susan's response to Aaron's statement about his homosexuality as a part of his identity, in fact, reflects Mormons' viewpoint that homosexuality is not a natural thing. Homosexuality is not something innately passed down on humans. In fact, based on the Bible (Romans 1: 24-32), they believe that homosexuality is against nature. Once a Mormon commits to homosexuality, he must show repentance to redeem his sin. Therefore, adhering to her Mormon belief, Susan furiously demands Aaron repent for his homosexuality.

In The Wise Kids, Tim-the main gay character of the movie, receives an adverse reaction from Laura (his best friend), which is provoked by his homosexuality. She preserves the belief that homosexuality is wrong according to the Bible. She keeps reiterating that the Bible contains God's words which are "important and holy". Therefore, despite how "confusing, weird, and complicated" the Bible is, Christians must live by it (Cone, The Wise Kids, 01:08:13-01:08:26).

Laura's statement that it is oxymoronic for someone to be Christian and gay at the same time actually represents the strong denunciation of homosexuality made by fundamentalist Christians. If looked thoroughly, Laura also represents those fundamentalists who take Biblical explanations literally to justify their opposition against homosexuality. In other words, fundamentalist Christians mostly misinterpret the Biblical verses on samesex relationships, hence religious homophobia frequently incited in this group (Sossa, 158). Ackley (2014), in his article for HuffingtonPost.com, mention that many fundamentalist Christians in the United States have carried out a literal application of the Biblical text, which lays the foundation of their discrimination against homosexuality.

Another major problem that is closely related to Biblical interpretation and homophobia is the strong bias and subjectivity towards sexuality, 
demonstrated by many interpreters and translators of the Bible. The bias undoubtedly reveals substantial “discrepancies” between the Biblical texts, interpretations, and real contexts. The discrepancies in the Biblical interpretations unfortunately may impose homophobic views among Christians, since the interpretations are underpinned from the translators' negative viewpoints on homosexuality (Sossa and Kane pp. 156157).

For instance, fundamentalist Christians often use the Biblical verse from Romans 1:26-27 as the common reference to condemn homosexuality (Sossa, 157). Romans are the compilation of letters written by Paul, one of Christ's disciples to his followers in Rome. According to Sossa and Kane, fundamentalist Christians have interpreted that the passage condemns homosexuality as sinful and unnatural (159). The phrase "vile affections" is not directly referred to homosexuality. Rather, it serves as Paul's assertion that Paganism is against nature and God's will; thus Christians must avoid it (160). However, fundamentalist Christians define "vile affections" by generalizing the "affections" as homosexual activities, since homosexuality has been denounced degrading and unnatural.

All movies highlight two similar points. The first point is the movies elucidate that American people who lead a very religious life are more likely to show opposition towards homosexuality. All gay characters must confront oppositions from their family members and friends who are known for their devotion to religious practices.

The depictions, thus, are consistent with the phenomenon where devoutly religious people in the United States support the condemnation on homosexuality. Shames, Kuo, and Levine (2011: 38) noted down that religious people in the United States who adhere to “religious traditions” (frequent attendances to the Church, Bible-reading and praying sessions) are more likely to defy homosexuality. They included the survey conducted by American National Election Studies (ANES) in 2008, which showed that people who frequently attend the Church and pray daily "prefer to ban homosexuality”, while people who less frequently attend the Church show more tolerance towards homosexuality.

Referring to the phenomenon where religions become the justifications for homophobia in the United States, it is 
riveting to see how in a secular country like the United States, religions still manage to wield its influence upon personal matters, namely marriage and sexuality. Merriman (2007: 46) argues that the states have a full control over personal matters, namely divorce, abortion, and even same-sex marriage. Hence, the state government is the authority given the full access to enforcing laws that regulate those personal matters. As Merriman quotes the statement by The Supreme Court, "laws are made for the government of actions, and while they cannot interfere with mere religious belief and opinions, they may with practices” (2007: 46). Consequently, religions should opt out their involvement in any matters that should be tackled by the government.

Nonetheless, religious groups keep urging the government to prohibit several issues and actions which are considered morally unacceptable to their religions. Same-sex marriage is the example in which religious groups have been pushing the government to take the opposing stance, since homosexuality is considered to be a "violation of their religion" (Merriman, 2007: 47). Until today, religious groups opposing same-sex marriage and homosexuality have been aggressively condemning the actions. In
2014, The Southern Baptist Convention's Ethics and Religious Liberty Commission held a conference encouraging faith leaders to oppose same-sex marriage (Bailey, 2014).

Despite the government's fervent attitude on the separation between religions and the state, the government still faces challenges in overcoming religious homophobia, which is also permeated in the official level. According to Merriman, the challenges exist since religions used to take control over personal issues, namely marriage and abortion for years. Besides, the government apparently establishes organizations that accommodate religious groups to address several issues becoming their concerns, namely homosexuality and abortion, to the government (Merriman, 2007: 28). In other words, through the organizations, those religious groups urge the government to resolve the issues. In consequence, it is problematic for the government to maintain the separation between religions and the state. Merriman further elucidates the matter in his discussion about challenges faced by the legalization of same-sex marriage,

Marriage was originally a church matter, and though it is now controlled by the state, religion is still intertwined with marriage in the eyes of many, even if the exact 
reasons for the connection cannot be articulated (2007: 47).

From the explanations above, it can be concluded that the three movies address the phenomenon where religious homophobia appears as one of the major issues confronted by the United States. Biblical interpretations and morality embody the justifications for the religious homophobia in the United States. Such justifications, ironically, have brought repercussions for religious homosexuals to reconcile their faiths and homosexuality.

\section{Homophobia and the Conformity to Traditional Gender Roles, Heteronormativity, and Masculinity}

In this section, the study discusses three movies: The Incredibly True Adventure of Two Girls in Love, Saving Face, and Dirty Girls. The first two movies are hugely concerned on homophobia in relation to gender roles and heteronormativity. On the other hand, the last movie deals with homophobia and masculinity.

The Incredibly True Adventure of Two Girls in Love and Saving Face deal with three lesbian characters Randy, Evie, and Wilhelmina who receive hostile reactions from their families and friends. Their families and friends conform to traditional gender roles and heteronormativity that denounce homosexuality as unacceptable. For instance, in the first movie, Randy and Evie, are shunned by their friends for establishing a lesbian romance. They are targeted to verbal slurs and resentment. Their experience connotes the conformity to heteronormativity and traditional gender roles.

Homophobia that is triggered by the conformity to gender roles can be seen through Randy's experience. Randy is slurred by her friends as dyke, the word used to refer to masculine lesbian women. The word is offensive because it is used by her heterosexual friends to identify her personality. As mentioned by Herbst, the word contains an offensive meaning as it indicates that lesbian women are unattractive and masculine (2001: 79). In other words, heterosexual people perceive lesbian women as strange since these women are accused of violating traditional gender roles which define them as feminine. As a result, lesbian women are also inseparable from homophobia and discrimination. According to Herek, Kite, and Whitley, gender roles and homophobia is closely connected (qtd. Garnets \& Kimmel, 2003: 150). They elucidate that homophobia reflects the "distrust of 
gender violation” for the perpetrators tend to conform to traditional roles (2003: 151). Also, the perpetrators tend to reject “equality between sexes" and have confining "family and gender roles" (2003: 151). From their explanation, it is explainable then why there is an inextricable link between gender roles and homophobia.

In addition to the aforementioned phenomenon, Garnets and Kimmel note down that members of Western societies privilege sexual orientation as the essence of one's identity (2003: 149). Most importantly, the emphasis of sexual orientation by the societies overlooks other essential elements shaping a person's identity, namely "gender, age, and sex" (2003: 149). Therefore they add people's "affectional and sexual lives" are considered overarching compared to other things (2003: 149). As western societies are mostly heteronormative, such a principle is used to impose heterosexuality and degrade homosexuality. Consequently, it also triggers discrimination and homophobia against homosexual people (2003: 150). The phenomenon is vividly reflected through Randy whose personality is devalued due to her homosexuality. The fact that she is a lesbian and is raised by a lesbian aunt makes her friends shun her.
Additionally, Evie, who is a popular girl, is shunned away by her best friends following her coming out. The fact that they open up about their homosexuality leads them to experience homophobia.

Similar with the first movie, Saving Face (2004) also explores the themes of homophobia, traditional gender roles, and heteronormativity. However, the movie specifically discusses those themes on grounds of Asian-American community, particularly Chinese-American community. Wilhelmina's reluctance to come out about her sexuality implies that the Chinese-American community enforces the conformity to heterosexuality as the acceptable sexual orientation. Wilhelmina is reluctant to come out as she fears the condemnation by her cultured Chinese-American family. In fact, her society strongly upholds the idea that having a husband can retain a woman's dignity and happiness. The movie perfectly captures the aforementioned phenomenon by showing Wilhelmina's mother who is very eager in finding a husband for Wilhelmina (Wu, Saving Face, 2:51; 56:41). Also, when there is a divorced woman at a Chinese-American gathering, other women will assume that the woman must live an unhappy life $(\mathrm{Wu}$, Saving Face, 8:27-8:33). 
Consequently, homosexuality is troublesome for the society. To such an extent, homosexuality can even be considered a disgrace for the society. The movie speaks up about the phenomenon through Wilhelmina's experience of coming out. After hiding her sexuality for years, Wilhelmina musters up the courage to come out while hoping that her mother will accept it. However, her mother (later will be called Ma) is not able to cope with it.

Wilhelmina's story can be regarded as the reflection of the concept of silence that determines the way Asian-Americans perceive sexuality. According to Takagi, the concept of silence has been prevalent within Asian-American communities for it connotes with good images of AsianAmerican community (1996: 26). Connecting sexuality and the concept of silence, sexuality is then seen invisible because it potentially ruins the good images sustained by Asian Americans. Takagi elucidates the connection between sexuality and the concept of silence by defining the concept as "the oppressive cost of a racially biased or heterosexist society” (1996: 26). Takagi's statement implies that the concept of silence represses gay Asian Americans to come out because they are cornered between declaring their true identity and being demanded to conform to "expected norms in society” (1996: 26).

The most intriguing issue about the concept of silence is the consequence that gay Asian Americans must endure once they come out. Takagi perfectly explains the issue through the concept of "in" and “out” (1996: 27). If someone chooses to hide their sexuality, he will never endure hostile reactions from his community. Instead if someone is "out" about his sexuality, he endures homophobic acts in forms of "exclusions" from his communities and being labeled as morally depraved (1996: 27). Such hostile reactions are not solely labeled to her but to her family as well (1996: 28). In fear of the consequences, gay Asian Americans are reluctant to come out to their family and community for the sake of sustaining dignity.

It is important to examine the thread between the aforementioned discussions and the movie. Wilhelmina's coming out as well as the homophobic reactions thrown by her mother and ChineseAmerican community perfectly represents the issues surrounding sexuality in Asian American community. Wilhelmina's preand post- coming-out experiences represent how Asian American people tend 
to restrain themselves from sexuality. Besides, it proves the idea that Asian Americans consider heterosexuality and traditional gender norms as the normative things in the society. Hence, when Wilhelmina insists on coming out as homosexual to public, homophobic reactions are the immediate responses she receives because the community believes that she has stripped her family of dignity.

The last movie, Dirty Girl (2010), comes up with masculinity as the trigger of homophobia. Different from the previous two movies, Dirty Girl revolves around Clarke, a gay student who struggles with his abusive yet homophobic father. Clarke's father, Joseph, has apparently discovered Clarke's homosexuality. Yet, he cannot fathom the fact that Clarke is gay. Instead, he sends Clarke to a psychological therapy and abuses him frequently, expecting that his son will turn masculine and straight. He even considers sending Clarke to military training to help Clarke convert his sexuality.

Clarke's experience regarding homophobia can be related to the manifested idea in which masculinity is highly honored by society. Hence, as men masculinity is attributed to men, the society demands men possess traits which enhance their dominant yet honored roles in society. Those traits comprise power, confidence, toughness, and courage. In other words, it can be said that the concept of masculinity has placed men to be the dominant human beings. In effect, the concept of masculinity has placed women to be subordinated and powerless (Donaldson qtd in Howson, 2006: 3).

The concept of masculinity, however, is problematic. Men might be attributed to masculinity. Nevertheless, the concept is never attributed to gay men (Donaldson qtd in Howson, 2006: 3). Connell argues that the exclusion of gay men from masculinity is inextricable from the fact that gay men display traits which are inverted from the manifest traits exhibiting masculinity (qtd in Howson, 2006: 79). In other words, gay men are associated with traits which are considered degrading to masculinity, namely being very expressive, effeminate, and powerless (Howson, 2006: 62).

Since gay men are defined with effeminate traits which are considered antithetical to masculinity (Kite and Deaux, qtd. Garnets \& Kimmel, 2003: 152), they become the frequent targets of homophobia. In other words, gay men are blamed for violating the traditional gender roles, particularly masculinity (Laner, Laner, and Storms, qtd. Garnets \& 
Kimmel, 2003: 152). At worst, hostile reactions due to the violation of masculinity are not only thrown at gay people. In fact, heterosexual people who play roles considered demeaning to masculinity are falsely labeled as gay (Deaux and Lewis, Storms et al, qtd. Garnets \& Kimmel, 2003: 152). For examples, a man who loves fashion, dislikes boasting about their sexual behavior, and shows no interest in sports are falsely claimed to be gay. In fact, their playing reversal roles do not always identify their sexual orientation. Hence, there is the phenomenon when people misconstrue gender roles with sexual orientation.

Returning to the movie, Clarke's homophobic father, Joseph, actually represents the phenomenon in which heterosexual men tend to be more homophobic than heterosexual women do. According to Kite and Whitley, such a phenomenon happens due to their conformity to masculinity (1993: 166). As they cited from numerous studies, heterosexual men show strong dislike against the term negatively perceives reversal gender roles and considers the tem homosexuality an insult to masculinity (Laner, Krulewitz, Nash, Preston, and Stanley, qtd. in Kite \& Whitley, 1993:
166). Additionally, according to Stockhard and Johnson, traditional male gender roles are more confining than traditional female gender roles (Stockhard and Johnson, qtd. in Kite \& Whitley, 1993: 166). This implies that men are strictly expected by the society to behave in accordance with their traditional male gender roles.

The traditional male gender roles are very restrictive that they "discourage tolerance" for people who "violate" traditional gender roles, especially masculinity (Kite \&Whitley, 1993: 166). This phenomenon is apparently prevalent in American society. According to Bern, American society persistently encourages the conformity to traditional gender roles (qtd Kite \& Whitley, 1993: 166). Therefore, men are strictly demanded not commit to things which are linked with femininity (Herek, qtd. in Kite \& Whitley, 1993: 166).

The aforementioned discussions, thus answer why Joseph becomes extremely abusive and homophobic against his gay son, Clarke. The conformity to traditional male gender roles which privileges masculinity triggers him to perpetrate homophobia against Clarke. Therefore, he will do anything, even if it is abusive, to get his son gain his masculinity. 
Homophobia and AIDS in the United States

In this section, the study studies Philadelphia (1993), Pedro (2009), and The Normal Heart (2014). These three movies are famous for distinctly capturing the actions initiated by gay men with HIV/AIDS, who despite battling with the illness, courageously fight for equality and raise the awareness of HIV/AIDS in the United States. For such distinct portrayals of AIDS and homophobia, the movies are thus used as the primary data for this section. In addition to the distinct portrayals, another reason underlying the selection of those movies is the fact that those movies are inspired by real-life events and figures. The fact that those movies are based on real-life events and figures will contribute to the profound and detailed explanations of the discussion regarding AIDS-related homophobia.

Philadelphia follows Andrew Beckett who is unfairly dismissed by his law-firm for being gay and suffering from HIV/AIDS. Pedro follows Pedro a gay man who is afflicted with HIV/AIDS and courageously raises the awareness of the epidemic. At last, The Normal Hearts follows a group of gay activist led by Ned Turner whose attempts to raise the awareness of HIV/AIDS within gay communities are confronted by homophobic members of American society.

Regarding the representation of AIDS-ridden homophobia in the three movies, those movies vividly capture the false association between HIV/AIDS and homosexuality which is hugely manifested in the United States. Moreover, the movies also depict moments where people unjustly blame gay people for their so-called unhealthy lifestyle which results in their affliction with HIV/AIDS. In other words, people ignorantly draw a conclusion that gay people deserve suffering from the epidemic since they have been deemed to live against moral and religious standards.

In Philadelphia, Andrew Beckett represents gay people who are victimized by the false association between AIDS, homosexuality, and sexual promiscuity. As mentioned previously, Beckett believes that his dismissal from the law firm is strongly connected with his homosexuality and his affliction with AIDS. Therefore, believing that he has been exposed to such an injustice, Beckett files a lawsuit against Charles Wheeler and partners as the owners of the law firm.

When the case is brought to the trial, Beckett brings in Melissa Benedict, a paralegal at the law firm where Beckett 
works, who also contracts AIDS. Some people at the law firm, including one leader of the firm, Walter Keaton has learned that Melissa contracts AIDS. Fortunately, Melissa is not fired since she is afflicted by AIDS from blood transfusion that she receives when delivering her second child. Melissa’s case makes Beckett's dismissal appear unfair to Beckett as he thinks that his dismissal is not solely triggered by AIDS but his homosexuality.

Pedro (2008) comes up with a more hopeful depiction of HIV/AIDS and homosexuality. In this movie, almost all heterosexual characters have comprehended that HIV/AIDS can be contracted by everyone. Nevertheless, AIDS-ridden homophobia appears as an inseparable issue from HIV/AIDS and homosexuality.

There is one important scene in Pedro that highlights AIDS-ridden homophobia in the United States. The scene shows Pedro who becomes a keynote speaker for an HIV-AIDS seminar. When he is going to enter the venue, he is confronted by a group of religious people who slur "God hates you!" to him. Also, they bring posters condemning Pedro's homosexuality and emphasizing that his HIV-AIDS is a punishment from God (Oceano, Pedro, 19:42-19:52). Pedro is finally able to speak at the seminar, despite the demonstration. However, he addresses the experience at the seminar by saying,

PEDRO. I really wish I had someone in my life who had told me how to protect myself because AIDS is not a moral dilemma or religious debate. It's a physical and mental health issue (Oceano, Pedro, 19:88-19:98).

Pedro’s experience being protested by the religious group resembles the fear of HIV/AIDS among religious groups in the United States. It also depicts the situation when religious leaders vocally argue that HIV/AIDS is the punishment of God, thus they must repent. Thus, the examination of HIV/AIDS in the United States is surrounded by the endless religious debates, which apparently also interrupt the process of researching the epidemic thoroughly.

The Normal Heart shows a bitter depiction of homophobia and HIV/AIDS in which a homophobic member of the US government refuses to help find solutions to curing the epidemic. It shows Ned meeting John Bruno, the advisor to the president of United States. John invites Ned to discuss the importance of researching HIV/AIDS for the country. Ned believes that the research will save 
people's lives from the epidemic. However, John is hesitant whether the research is useful for the country since he believes that it hardly affects heterosexual people. In other words, he implies that the epidemic solely afflicts gay people, thus he considers the epidemic unnecessary to be subjected to a serious scrutiny.

The devastating portrayals of AIDSridden homophobia in Philadelphia, Pedro, and The Normal Heart are riveting to probe. All movies are set in the1980s1990s, in which there was the outbreak of HIV/AIDS in the United States. During those years, the responses towards HIV/AIDS were enclosed with negative prejudice against gay people. For the most part, the majority of American people denounced HIV/AIDS as the consequence that gay people had to suffer. Correspondingly, people declined to direct urgent attentions towards gay people with HIV/AIDS.

One major impulse of the denunciation was the representation of gay people in the media. Gay people were considered to be the carriers of the disease, as the media had claimed that the AIDS epidemic was mostly found in gay people. An article from The New York Times entitled "Rare Cancer Seen in 41 Homosexuals" was the first news article that broke the silence about the epidemic. In the article, the journalist Lawrence $\mathrm{K}$. Altman, wrote that HIV/AIDS was rapidly transmitted within gay communities for they had "multiple” sexual encounters with different partners.

At worst, Benshoff (2006: 203) noted that media also made ignorant statements by "polarizing” heterosexuals as "clean-living" people and gay as “disease-ridden queers.” He further added that the representation became exacerbated as people with HIV/AIDS (both heterosexuals and homosexuals) were classified as "innocent” heterosexuals and “deserving” homosexuals. Innocent heterosexuals refer to the statement that heterosexual people could contract with HIV/AIDS from blood transfusions and needles (2006: 203). Conversely, "deserving" homosexuals is the term implying that gay people deserve HIV/AIDS as the punishment for committing unhealthy sexual lifestyle (2006: 203).

HIV/AIDS as the punishment for gay people was the concept that hugely pervaded in American society. Inevitably, the idea unleashed fear and hatred against gay people. People feared of contracting the disease while reproaching gay people for carrying the disease. The fear and 
hatred could be strongly associated to the fact that gay people, whether contracting from AIDS or not, belonged to "feared and disliked groups” in the country (Stoddard and Rieman, 1991: 254). Hence, the situation made gay people with AIDS prone with the danger of injustice and medical negligence.

As mentioned previously, in the United States, such a portrayal has hugely influenced the way people perceive and respond to the disease. Gay people are victimized by the demeaning portrayal. They are denied the chance to get the proper medical assessment. Their chance to live a normal life is even restricted because people have fear of getting afflicted with the epidemic.

The role of media in framing HIV/AIDS and homosexuality in The United States was intriguing since it had fundamentally manifested adverse reactions towards gay people with AIDS within American society. According to Dyer, since 1970s, representation has become an essential foundation in shaping a society's attitudes towards social and cultural phenomena (qtd.in Watney, 1987: 8). Moreover, he adds that representation has been very powerful in determining the access given to any social group to access “political chances” (1987: 9). Most importantly, he argues that representations in mass media play a key role in conceptualizing how a social group can contribute to society (1987: 9).

Dyer's explanation is then in accordance with what happened with the American society following the media coverage on HIV/AIDS and its association with homosexuality. People relied on the media coverage because they claimed that it spoke the truth (Watney, 1987: 9). When media came up with the information on homosexuality and HIV/AIDS which demeaned gay people, people believed that the coverage told the truth. Hence, what had been represented in the media about HIV/AIDS and homosexuality was used as the justification for the AIDS-ridden homophobia.

One irking point to probe is the reasons underlying the homophobic media coverage on AIDS and homosexuality. As explained previously, media was responsible for AIDS-ridden homophobia in the United States due to their reports that tend to demean and accuse gay people for HIV/AIDS. Personal judgment and biases against gay people undeniably prompted journalists to write such reports. Gross stated that journalists failed to dissolve their biases against gay people when reporting the news on the epidemic 
(2001: 101). Furthermore, an American journalist, James Kinsella, wrote that "homophobia among media personnel" intimidated journalists concerned on providing in-depth yet unbiased news on HIV/AIDS and homosexuality (qtd. in Gross, 2001: 101). Dismissal and "suspicions of being gay" were the threats that daunted journalists who endeavored to correct the misleading representation of those issues (2001: 101).

At last, it can be concluded that the movies do not only represent AIDS-ridden homophobia by displaying the horrifying images of the epidemic and homophobia. The AIDS-ridden homophobia is ferociously festering for gay people, as they are exposed to both physical and mental sufferings. Nevertheless, the injustices and indignities which they endure spur them to fight for their lives.

Beckett, Pedro, and Ned are not just represented as victims of homophobia. They are portrayed as heroes and inspirations for gay people to keep fighting for equality. Ryan Murphy, the director of The Normal Heart, mentions that the movie aims to remind young gay people of the struggle for achieving equality (Fleming, Jr.). Also, he hopes that the movie can pass on Ned's relentless yet courageous spirit to gay people in this generation. Thus, they are able to possess the same spirit when striving for equality (Fleming, Jr). The same statement is also made by Dustin Lance Black, the scriptwriter of Pedro. He hopes that the movie can encourage young people, particularly those who come from gay community, to inherit Pedro's spirit in obtaining justice (TV Guide, 2009).

\section{Conclusion}

The study examined the representations of homophobia in nine American gay-themed movies produced in 1990s to 2010s. From those nine movies, there are three representations of homophobia in the United States which encompass religions, gender roles, heteronormativity, masculinity, and HIV/AIDS.

Three movies, But I am Not A Cheerleader (1999), Latter Days (2003), and The Wise Kids (2011), represent how religions, specifically from fundamentalist Christian denominations, play a major factor in inciting homophobia in the United States. The religious beliefs perceive homosexuality as inimical and against procreation. Consequently, religious groups use the beliefs to justify their homophobia. This phenomenon appears as the most serious peril for gay 
people who endeavor to reconcile their faiths and sexuality. Furthermore, another peril that gay people endure is the coercion to undergo coercion therapy, which is an act exhibiting homophobia by religious people.

The representations of homophobia and religions in those movies are intriguing to probe in relation to the country's identity as a secular country. Despite being secular, the country apparently manages to accommodate religious groups to address their issues (in which homosexuality turns to be one of the issues). The situation leads religions (through its institutions) to retain their control over private matters namely marriage and sexuality, despite the government has enacted laws regarding the matters. Hence, it leads challenges for the government to tackle homophobia that is triggered by religions.

Other three movies, The Incredibly True Adventure of Two Girls in Love (1995), Saving Face (2004), and Dirty Girl (2010) present another representation of homophobia. These movies accentuate the fact that homophobia is triggered by the conformity to traditional gender roles and heteronormativity. Traditional gender roles and heteronormativity demand society submit themselves to masculinity, femininity, and heterosexuality as the norms to live by. Homosexuality is seen as the violation to traditional gender roles and heteronormativity. Hence, gay people are targeted to homophobic actions (in forms of humiliations, resentment, verbal slur, and physical abuse), because they are accused of violating traditional gender roles and heteronormativity.

The last three movies, Philadelphia (1993), Pedro (2008), and The Normal Heart (2014) render the inextricable link between homophobia and HIV/AIDS in the United States. The movies chronicle the struggle of gay people in confronting the AIDS-ridden homophobia. Gay people who are afflicted with the epidemic suffer injustice and homophobic treatments which endanger their lives. The injustice and homophobic treatments are caused by the media representation that tends to accuse gay people as the carriers of the epidemic.

At last, those are three major representations of homophobia in the United States as seen in gay-themed American movies produced in 1990s2010s. Nowadays, the country is wellreputed for its acceptance towards gay communities. Nevertheless, homophobia remains a huge challenge to tackle due to 
the fact that it has been institutionalized for years.

Regarding the continuous depictions of homophobia in gay-themed American movies, the movies aim to educate people about the struggle of gay people to achieve positive recognitions. Also, the movies apparently serve as the message for gay people to keep striving for justice and addressing their issues. Hence, they can receive equality.

\section{References}

2013 Studio Responsibility Index." GLAAD. N.p., 20 Aug. 2013. Web. $26 \quad$ June 2016 http://www.glaad.org/sri/2013/

"2014 Studio Responsibility Index." ISSUU. ISSUU, n.d. Web. 26 June 2016. $<$ https://issuu.com/glaad/docs/2014_ sri_v5/31?e=6038659/8660738>.

"2015 Studio Responsibility Index." ISSUU. ISSUU, n.d. Web. 26 June 2016.

$<$ https://issuu.com/glaad/docs/glaadsri-2015_reviewv04-hires>.

"2016 Studio Responsibility Index." ISSUU. ISSUU, n.d. Web. 26 June 2016.

$<$ https://issuu.com/glaad/docs/2016_ sri $>$.

"Chastity | Sexual Purity - Chaste and Morally Clean." The Church of Jesus Christ of Latter-Day Saints. N.p., n.d. Web. 25 Mar. 2016
$<$ https://www.lds.org/topics/chastity ?lang=eng $>$

"Chapter 1 | The Epistle of Paul to the Apostle to the Romans." The Church of

Jesus Christ of Latter-Day Saints. N.p., n.d. Web. 25 Mar. 2016 $<$ https://www.lds.org/scriptures/nt/ro $\mathrm{m} / 1.27>$.

"Same-Sex Attraction | LDS Church Perspective on Chastity." The Church of

Jesus Christ of Latter-Day Saints. N.p., n.d. Web. 25 Mar. 2016. <https://www.lds.org/topics/samegender-attraction?lang=eng $>$

Ackley, H. Adam. "The Joy of Gay Sex, Michael Sam and Biblical Literalism: Let's Not Take It Lying Down." The Huffington Post. TheHuffingtonPost.com, 15 May 2014. Web. 26 Mar. 2016. $<$ http://www.huffingtonpost.com/ h-adam-ackley-phd/the-joy-ofgay-sex-

michae_b_5321003.html>.

Altman, Lawrence K. "RARE CANCER SEEN IN 41 HOMOSEXUALS." The

New York Times. The New York Times, 02 July 1981. Web. 20 May 2016.

<http://www.nytimes.com/1981/07/03/ us/rare-cancer-seen-in-41homosexuals.html>.

Bailey, Sarah Pulliam. "Progressive Evangelicals Launch Campaign to Expand Christian Support for Same-Sex Marriage." The Huffington Post. TheHuffingtonPost.com, 15 Sept. 
2014. Web. 4 Apr. 2016. http:/www.huffingtonpost.co m/2014/09/15/us-evangelicals-gaymarriage_n_5824174.html.

Benshoff, Harry M. \& Griffin, Sean. 2006. "Queer Images: A History of Gay and Lesbian Film in America.” Lanham, MD: Rowman \&Littlefield Publishers, Inc. Print.

Bronski, Michael. Ed. Cynthia A. Barto Lucia, Roy Grundmann, and Art Simon. 2016. American Film History: Selected Reading. West Sussex: John Wiley \& Sons. 330-43. Print.

Bronski, Michael. 2011. A Queer History of the United States. Boston: Beacon Press. Print.

Bullough, Vern. (2005). When Did the Gay Rights Movement Begin?. Historynewsnetwork.org. Retrieved on April 16, 2015 from $<$ http://historynewsnetwork.org/articl e/11316>

But I'm A Cheerleader. 1999. Dir. Jamie Babbit. Perf. Natasha Lyonne, Clea DuVall, RuPaul Charles, and Cathy Moriaty. Lionsgate. Film.

Davis, Tracy J. (2005). "Homophobia and Media Representations of Gay, Lesbian, Bisexual, and Transgender People”. Encyclopedia of Interpersonal Violence.ed. Claire M Renzetti \& Jefrrey L. Thousand Oaks, CA. Sage Publication. 2008, 338-339.

Dirty Girl. 2010. Dir. Abe Sylvia. Perf. Juno Temple, Jeremy
Dozier, and Milla Jovovich. The Weinstein Company. Film.

Federal Bureau of Investigation. "FBIVictims”.fbi.gov. Retrieved on December16, 2015 from https://www.fbi.gov/news/stories/ 2014/december/latest- hatecrime-statistics-report-released.

Fleming Jr., Mike. "Emmy Q\&A: Ryan Murphy On The Long Road To 'The Normal Heart"' Deadline. Deadline, 31 July 2014. Web. 30 May 2016. $<$ http://deadline.com/2014/07/emm y-qa-ryan-murphy-on-the-longroad-to- the-normal-heart812931/>.

Garnets, Linda, and Douglas C. Kimmel. 2003. Psychological Perspectives on Lesbian and Gay Male Experiences. 2nd ed. New York: Columbia UP. PDF.

Girshick, Lori. B. (2005). "Homophobia”. Encyclopedia of Interpersonal Violence.ed. Claire M Renzetti \& Jefrrey L. Thousand Oaks, CA. Sage Publication. 2008, 336-338.

Gregory, Sean. "U.S. Ranks Worst in Sports Homophobia Study." TIME. TIME, 9 May 2015. Web. 19 June 2015. $<$ http://time.com/3852611/sportshomophobia-study/>.

Gross, Larry. 2001. Up From Invisibility: Lesbians, Gay Men, and The Media in America. New York. Columbia University Press. Print.

Hall, Stuart. 2003. Representation: Cultural Representations and Signifying Practices.Thousand Oaks: Sage Publication, Inc. Print. 
Herbst, Phillip H. 2001. "Dyke, Dike." Wimmin, Wimps \& Wallflowers: An Encyclopaedic Dictionary of Gender and Sexual Orientation Bias in the United States. Yarmouth: Intercultural.

Howson, Richard. 2006. Challenging Hegemonic Masculinity. London: Routledge. PDF.

Jagose, Annamarie. 1996. Queer Theory: An Introduction. New York: New York University Press. PDF.

Kite, Mary E., and Bernard E. Whitley, Jr. 1993. "Do Heterosexual Women and Men Differ in Their Attitudes Toward Homosexuality? A Conceptual and Methodological Analysis." Ed. Linda Garnets and Douglas C. Kimmel.Psychological Perspectives on Lesbian and Gay Male Experiences. New York: Columbia UP. 165-87. PDF.

Lance Black, Dustin. "Getting Real" TV Guide. p. 66. March 30, 2009.

Latter Days. Dir. C. Jay Cox. Perf. Max Sandvoss and Wes Ramsey. TLA Releasing, 2003, Film.

Merriman, Scott A. 2007. "Personal Issues of Religion and State." Religion and the Law in America: An Encyclopedia of Personal Belief and Public Policy. Vol. 1. Santa Barbara, CA: ABC-CLIO. 45-50. PDF.

Moore, Gareth. 2003. A Question of Truth: Christianity and Homosexuality. London: Continuum. Google Books. Web. 18 Mar.
2016. https://books.google.co.id/boo ks?hl=id\&lr=\&id=FBkghgDbZ1gC \&oi $=\mathrm{fn}$ $\mathrm{d} \& \mathrm{pg}=$ PR5\&dq=moore+christianity +homosexuality\&ots=D0pPtVrouB \&s

ig=Tt76BWzONXiSXKwkxfBEAc A0HgM\&redir_esc $=\mathrm{y} \# \mathrm{v}=$ onepage $\&$ $\mathrm{q}=$ moore\%20christianity\%20homosex uality\&f=false.

Pedro. Dir. Nick Oceano. Perf. Alex Loynaz and Justina Machado. Wolfe Video, 2008. Film.

Philadelphia. Dir. Jonathan Demme. Perf. Tom Hanks and Denzel Washington.TriStar Pictures, 1993. Film.

Reilly, Mollie. "Obama Praises Supreme Court's Decision To Legalize Gay Marriage Nationwide." Huff Post Politics. Huffington Post, 26 June 2015. Web. 16 Dec. 2015.

Roggemans, Lilith., Spruyt, Bram., Droogenbroeck, Filip Van., Keppens, Gil.2015. Religion and Negative Attitudes towards Homosexuals: An Analysis of Urban Young People and Their Attitudes towards Homosexuality. pp.254-276. Retrieved on Feb 19, 2016 from http://you.sagepub.com

Rowe, John Carlos. 2000. PostNationalist American Studies. Berkeley: University of California Press. Print.

Sands, Kathleen 2007. "Homosexuality, Religion, and the Law." Homosexuality and Religion: An Encyclopedia. Ed. 
Jeffrey S. Siker.Westport, CT:

Greenwood Press. PDF.

Saving Face. Dir. Alice Wu. Perf. Michelle Krusiec, Joan Chen, and Lynn Chen. Sony Pictures Classics, 2004. Film.

Shames, Shauna L., Katherine Levine, and Didi Kuo. 2011. "Culture War? A Closer Look at the Role of Religion, Denomination, and Religiosity in US Public Opinion on Multiple Sexualities." Ed. David Rayside and Clyde Wilcox.Faith, Politics, and Sexual Diversity in Canada and The United States. Vancouver: UBC. 29-48. Web. 5 May 2016.

Shidlo, Ariel. (1994). "Internalized Homophobia: Conceptial and Empirical Issues in Measurement”. Lesbian and Gay Psychology: Theory, Research, and Clinical Applications.ed. Beverly Greene \& Gregory M. Herek. Thousand Oaks, CA. Sage Publication. 176-205.

Stoddard, Thomas B., and Walter Rieman. 1991. "AIDS and the Rights of the Individual: Toward a More Sophisticated Understanding of Discrimination." Ed. Dorothy Nelkin, David P. Willis, and Scott Parris. A Disease of Society: Cultural and Institutional Responses to AIDS. Cambridge: Cambridge UP. 241-72. PDF.

Takagi, Dana Y. 1996. "Maiden Voyage: Excursion into Sexuality and Identity Politics." Ed. Russell Leong. Asian American Sexualities: Dimensions of the Gay and Lesbian Experience.
New York: Routledge. 21-36.

PDF.

The Incredibly True Adventure of Two Girls in Love. Dir. Maria Maggenti. Perf.Laurel Holloman and Nicole Ari Parker. New Line Cinema, 1995. Film.

The Normal Heart. Dir. Ryan Murphy. Perf. Mark Ruffalo, Matt Bomer, Julia Roberts, and Taylor Kitsch. HBO, 2014. Film.

The Wise Kids. Dir. Stephen Cone. Perf. Molly Kunz, Allison Torem, Tyler Ross, and Stephen Cone. Wolfe Video, 2011. Film.

Tin, Louis-Georges. (2003). The Dictionary of Homophobia. Vancouver: ArsenalPulp Press.

Watney, Simon. 1987. Policing Desire: Pornography, AIDS, and the Media. Minneapolis: University of Minnesota. PDF. 